\title{
Information Literacy Competency Standards for Higher Education and their Correlation with the Cycle of Knowledge Generation ${ }^{1}$
}

\author{
Alejandro Uribe Tirado \\ Interamerican School of Library and Information Science, \\ the University of Antioquia (Medellín-Colombia), \\ auribe@bibliotecologia.udea.edu.co
}

\section{Wilson Castaño Muñoz}

Interamerican School of Library and Information Science, the University of Antioquia (Medellín-Colombia), wilsoncastano@bibliotecologia.udea.edu.co

\begin{abstract}
This article considers the cycle of knowledge generation proposed by Nonaka and Takeuchi and sets out how the different indicators and expected results within the information literacy (IL) standards used in higher education contribute to this cycle. After analyzing each standard and its interrelation with the four options to generate knowledge of Nonaka's cycle, it was identified that these standards are more geared to the generation of explicit knowledge, and therefore, it is necessary to work on other activities, and new proposed standards of IL that promote the generation of tacit knowledge and information processes needed.
\end{abstract}

Key Words: information literacy; information competencies; information literacy standards; knowledge management; access to knowledge; university libraries 


\section{Introduction}

This article strives to merge two concepts and practices that have been largely developed over recent decades. One of these concepts comes from the information literacy (IL) field of library and information science, and the other is related to the knowledge management (KM) field of business, but also known in library and information science.

Unfortunately, as indicated by Ferguson (2009, p. 20), the relationships among $\mathrm{KM}$ and IL concepts and practices have not always been perceived because these two concepts come from different fields.

“...the bridge provided by the workplace IL model does draw attention to the fact that there is a gap between the traditional view of IL (however much that may have moved beyond a procedural approach) and the knowledge literacy promoted by KM proponents. Some of the skills, attitudes and abilities associated with knowledge literacy do not relate to formal educational environments but to a different type of 'learning organisation', one in which knowledge, taken to include explicit forms (information) as well as tacit, embedded, procedural and anecdotal knowledge, is seen as the life-blood of a corporate organism that needs to adapt quickly to its external environment, such as the market, competition, government regulation or globalisation. KM's focus is on the organisational perspective, as a 'learning organisation', and hence on ensuring that information is readily available and renewable and that individual capacities and knowledge sharing processes support the required levels of organisational learning.

If, indeed, KM's focus on the organisational perspective, that of an organic, adaptive learning organisation, is a long distance from the largely individual focus of IL, as it is traditionally understood and practiced, might it be worth considering the operational perspective and specifically the scale at which one is operating. Could it be that both IL and $\mathrm{KM}$, in the context discussed here, might well benefit by thinking in scalar terms or, in other words, in terms of a total or general knowledge/ information space, global and local, from the micro through the meso to the macro, and vice versa?..."

Our answer to Ferguson's final question is, yes, and so this article seeks to generate an analysis, and initial proposal of how, from the field of education, 
training in information literacy can contribute to the generation of people competent in information, "in terms of a complete or general knowledge/ information space, global and local, from the micro through the meso to the macro, and vice versa".

Thus, before looking more deeply into specific issues in both fields, it is necessary to define the terms information literacy and knowledge management, and to outline the scope of this article and its intended framework.

\subsection{Information literacy}

Paul G. Zurkowski (1974, p. 6) first used the term information literacy to describe the techniques and skills necessary to be able to utilize "a wide range of information tools as well as primary sources". Zurkowski's definition of information literacy also included the ability to measure information value, to "mold information to [meet] needs" and to create solutions to problems.

In the ensuing four decades, the concept of information literacy has developed to include multiple definitions, models, standards, best practices, and declarations (UNESCO/NFIL, 2003; Garner, 2006). Since Zurkowski's coining of the concept of information literacy, researchers around the world have worked to explore and expand the concept (Saranto \& Hovenga, 2004; Lau, 2007; Horton, 2012), resulting in a range of definitions of information literacy and a myriad of standards and guidelines for information literacy teaching and training.

Although literature related to information literacy exists in many languages, for the purposes of this article and referring back to previous research (UribeTirado, 2009a), we considered 20 proposals and pieces of work by different authors and organizations that have defined and described what information literacy is. These can be interrelated, according to the words and the emphasis of their definitions and descriptions (Figures 1 and 2), by using bibliometric and information visualization techniques (clustering, multidimensional scaling, factorial, pathfinder networks), discourse and content analysis.

The figure below shows a wide definition and broad description of information literacy. Key words and emphases put forward by the authors mentioned 
Fig. 1: Interrelationship between the authors and organizations who have defined the concept of information literacy (Uribe-Tirado, 2009a).

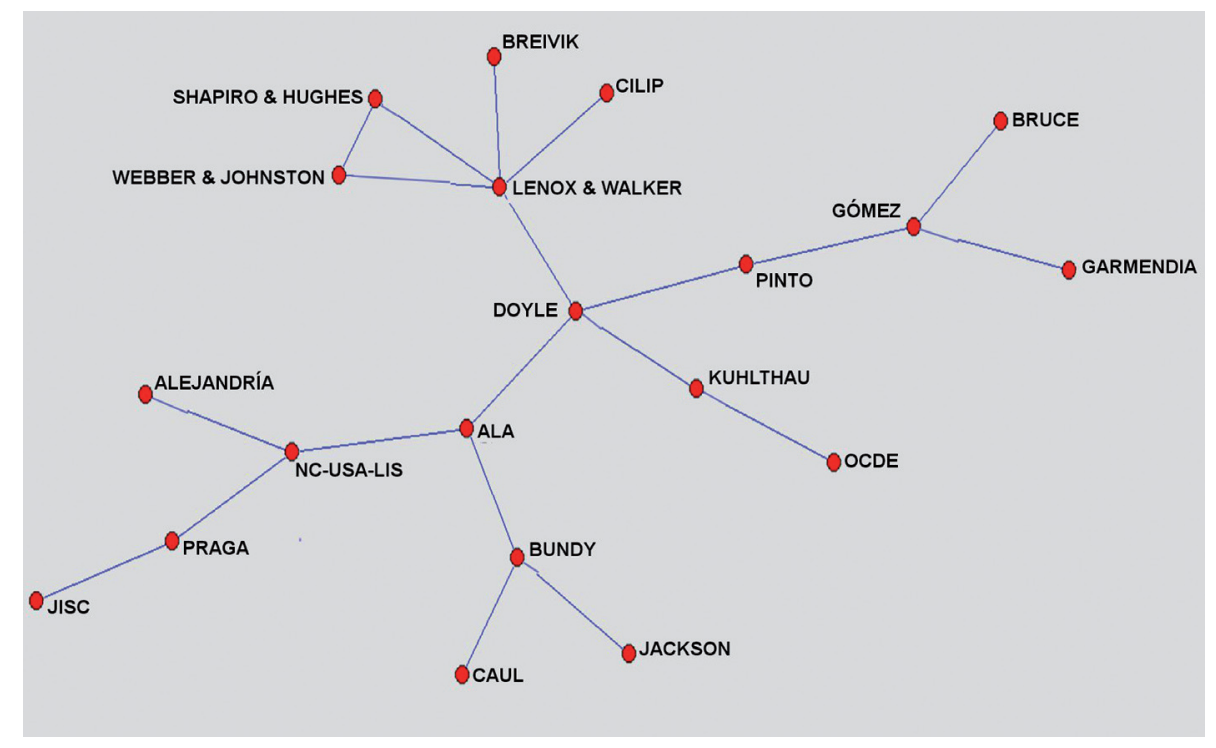

in Figure 1 make up the proposed definition. The central nodes are: information access and retrieval (locate-search-access), knowledge generation (create-generate knowledge) and its impact on organizations and society (organizations-communities-nations), along with all the fundamental variables that should be included in the process of the acquisition of information literacy: targets, mediators, teaching strategies and learning environments, competencies and multiliteracies, etc.

Therefore, this article, will define information literacy, in summary, as:

"The teaching-learning process designed for an individual or group of people, under the professional leadership and guidance of an educational or library institution, using different teaching strategies and learning environments (classroom, mixed-blended learning or "virtual"). Its purpose is to achieve competencies (knowledge, skills and attitudes in computing, communications and information) that would enable, after identifying and recognizing their information needs, to locate, select, 
Fig. 2: Interrelationship between the concepts present in the 20 analyzed definitions of the term Information Literacy (Uribe-Tirado, 2009a).

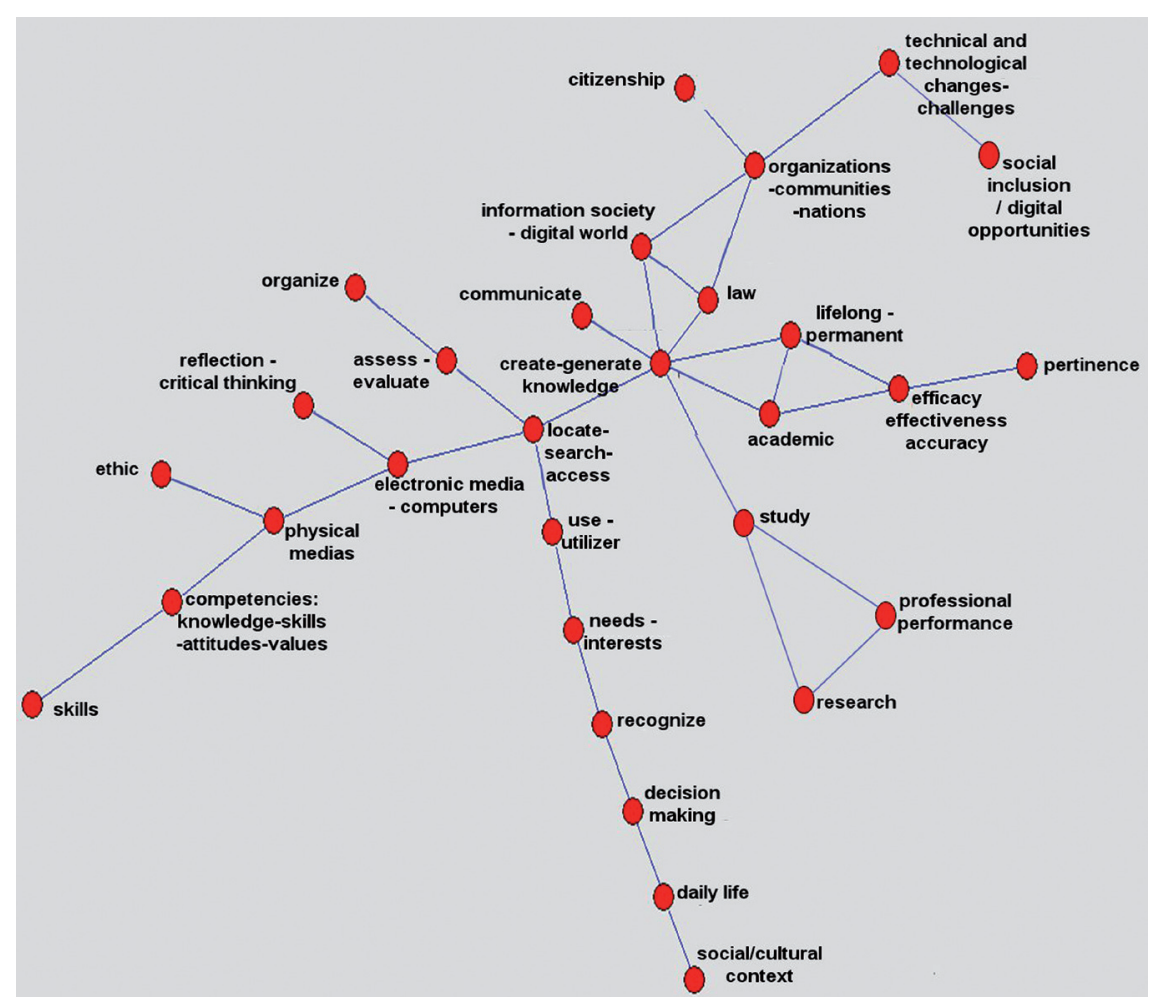

retrieve, organize, evaluate, produce, share and disseminate information in an efficient and effective way..."

Uribe-Tirado, 2009a (Translated from Spanish)

\subsection{Knowledge management}

Over the last three decades, parallel to the development of information literacy, two practical theoretical trends from management (organizational learning and organizational knowledge) have been identified, developed and adapted to new demands from today's society (Easterby-Smith \& Lyles, 2003). This is not an isolated result of changes triggered by advances in information 
and communication technology (ICT), but, in a mutually complementary way, it is a result of the changes generated by the way goods and services are produced, allowing for the generation of wealth.

Close to the previous notions of organizational learning and organizational knowledge is the concept of digital divide (Van Dijk, 2005), existing (and increasing!) among and between information-led countries and/or societies on the one hand, and groups of people (e.g., in developing countries), who are still more dedicated to cultivating the land than to information and knowledge on the other hand.

Within this context, the two previously mentioned trends (organizational learning and organizational knowledge) that frame the developments in this management field are moving from the process perspective to the contentresult perspective (i.e., information $\rightarrow$ learning $\rightarrow$ knowledge) and from theory to practice. They create what is called "organizational learning" and "the organization that manages its knowledge", meaning "knowledge management" (Easterby-Smith \& Lyles, 2003).

There are multiple definitions from different authors ${ }^{2}$ and organizations ${ }^{3}$ for these correlated concepts, but this study chooses to hold an integrative understanding which is possible within a general framework, such as that set out by Vera and Crossan (2003) in their study "Organizational Learning and Knowledge Management: Toward an Integrative Framework." Therefore, as an integrated proposal, this study will define knowledge management as:

A process that uses different strategies and tools to facilitate the creation, understanding, structuring, dissemination, acquisition and/or application of specific knowledge, whether explicit or tacit (content-results), which is held by people who are part of an organization or by an organization itself. It also aims to generate new information, which will interact with individuals-groups' previous knowledge and experience in order to bring about new learning and therefore augment personal and organizational knowledge (know-how, intellectual capital).

This definition of what is known as knowledge management uses the correlation between tacit and explicit knowledge put forward by Nonaka and Takeuchi (1995) in their concept of the "Knowledge Spiral Conversion Model" as a key issue (Figure 3): 
Fig. 3: "Knowledge Spiral Conversion Model" (Adaptation of Nonaka E Takeuchi, 1995).

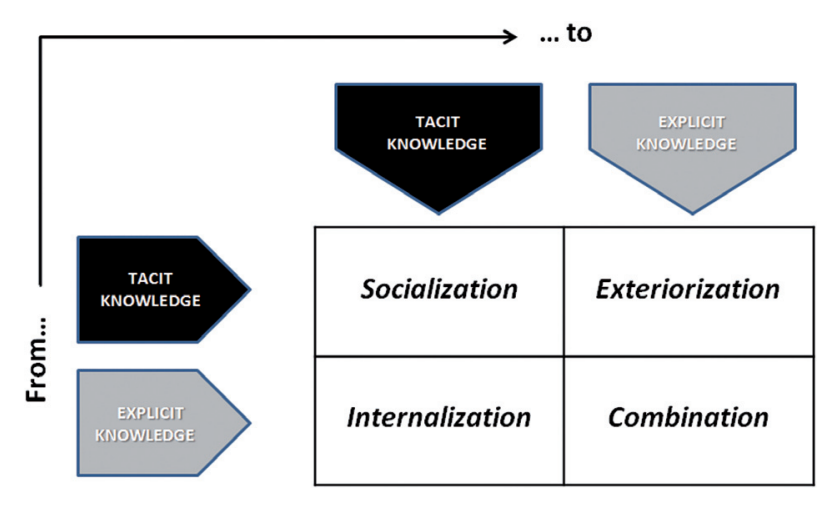

Socialization: is the process through which a person acquires someone else's tacit knowledge by observation, imitation, practice and dialog.

Exteriorization: is the process through which a person acquires someone else's tacit knowledge. This person consciously shares his/her tacit knowledge by using metaphors, analogies, concepts, hypotheses and models that make tacit knowledge explicit.

Combination: is the knowledge exchange process in which modes of interaction and understanding of explicit knowledge are transferred, through the use of printed and digital content (texts, reports, slides, audio, videos, etc.) and the use of different methods of communication (meetings, conversations, intranets, the Internet, etc.).

Internalization: is the process through which a person integrates knowledge acquisition to his/her knowledge and experience (learning-tacit mental structures), which enables the socialization, exteriorization and combination processes, and in which the individual becomes aware of the new base of knowledge and shares it with others, creating a new Cycle of Knowledge Generation (Conversion).

\section{Literature review}

Across the last thirty years of developments in the field of information literacy, different authors have produced a range of proposals using diverse 
pedagogical methods and standards, mostly within the ambit of universities. These proposals have had a major influence on the development of the theoretical framework in this field:

"An information literacy model is a framework that aims at defining which levels of competence a person should master before he/she can acquire the skills that make him/her information literate. The operational development of these models is carried out through standards, made up of lists of categories that describe the nature of these models." (Cuevas Cerveró, 2007) (Translated from Spanish)

Therefore, considering the relationship between models and standards and their correlation with the different forms of knowledge generation (conversion) from tacit to tacit (socialization), from tacit to explicit (exteriorization), from explicit to explicit (combination) and from explicit to tacit (internalization), a literature review was conducted with the aim of identifying which pedagogical models and standards were most commonly used and bestknown among information literacy experts worldwide (Uribe-Tirado, 2008, 2010).

The literature review was carried out using sources of information such as SCIENCE DIRECT, SCOPUS, EBSCO: Academic Search Premier, LISA and E-LIS. The use of these resources along with specific books and articles ${ }^{4}$ allowed for the identification of the following relevant and well-known Information Literacy standards and models:

\subsection{Information Literacy Teaching Models}

The most important models for academic institutions include:

1. Seven Faces of Information Literacy by Christine Bruce (Australia, 1997)

2. The Seven Pillars of Information Literacy - SCONUL (UK and Ireland, 1999)

3. Sauce Model by Bond (New Zealand, 2001)

4. The Big Blue - Taxonomy of information skills (England, 2002)

5. The Seven Steps of the Research Process (United States, 2003)

6. Web-Based Information Searching by Sylvia Edwards (Australia, 2004) 
7. Six Frames for Information Literacy Education by Christine Bruce et al. (Australia, 2006)

8. A Framework by Markless and Streatfield (2007) (England).

In the field of school libraries, and with influence in the university sector, the following models stand out:

1. Research Steps to Success by Hunges (Canada, 1998)

2. The 8 Ws by Lamb (United States, 1990)

3. Search Process Model by Kuhlthau (United States, 1985-2008)

4. The Big Six Skills (United States, 1990, 2000)

5. Digital Information Fluency-DIF (United States, 2001)

6. PLUS Model by Herring (Scotland, 2002)

7. Information Literacy Scope and Sequence (United States, 2003)

\subsection{Information Literacy Standards}

In terms of standards and models relating directly or indirectly to the academic sphere, the following can be mentioned:

The United States:

1. "Information Literacy Competency Standards for Higher Education" (ALA/ACRL, 2000).

2. “Objectives for Information Literacy Instruction: A Model Statement for Academic Librarians"; where indicators and standards are integrated with more specific objectives to facilitate teaching-learning process for some expected outcomes (ALA/ACRL, 2001).

England:

1. "Society of College, National and University Libraries"; linked to the Seven Pillars of Information Literacy model (SCONUL, 1999). ${ }^{5}$

Australia/New Zealand:

1. "Council of Australian University Librarians"/The Australian and New Zealand Institute for Information Literacy" (CAUL, 2001/ ANZIIL, 2004). 
Norway:

1. "The Nordic Council for Scientific Information" (NORDINFO, 2001).

As regards standards for school libraries, the following stand out:

1. United States: American Association of School Librarians and the Association for Educational Communications and Technology -AASL/AECT-, 1998

2. Canada: The Students' Bill of Information Rights/Students' Information literacy Needs in the 21st Century: Competencies for Teacher-Librarians (for school libraries, but influenced by academic libraries) by the Association for Teacher-Librarianship in Canada (ATLC) and the Canadian School Library Association (CSLA), 1997.

It is important to mention that over the last decade some models and standards have been proposed and developed in Latin America, Spain and Portugal, but their impact has so far been local.

These models include Spain's ALFIN-EEES Standard (Pinto, 2004, Pinto, Sales \& Osorio 2007) and Mexico's Standards on Information Literacy in Higher Education, by the Universidad Autónoma de Ciudad Juárez (Cortés \& Lau, 2004).

\section{Methodology}

After identifying these models and standards a qualitative analysis (content analysis and discourse analysis) was carried out, in which the different components put forward by the models as training cycles/sequences for information literacy were contrasted with the macro and micro skills described in the standards.

This analysis was based on the Guidelines on information literacy for lifelong learning published by IFLA (Lau, 2006) and the Information Literacy Indicators by UNESCO (Catts \& Lau, 2008), and an integrative proposal for Information Literacy (Uribe-Tirado, 2008, 2010) as shown in Table 1: 


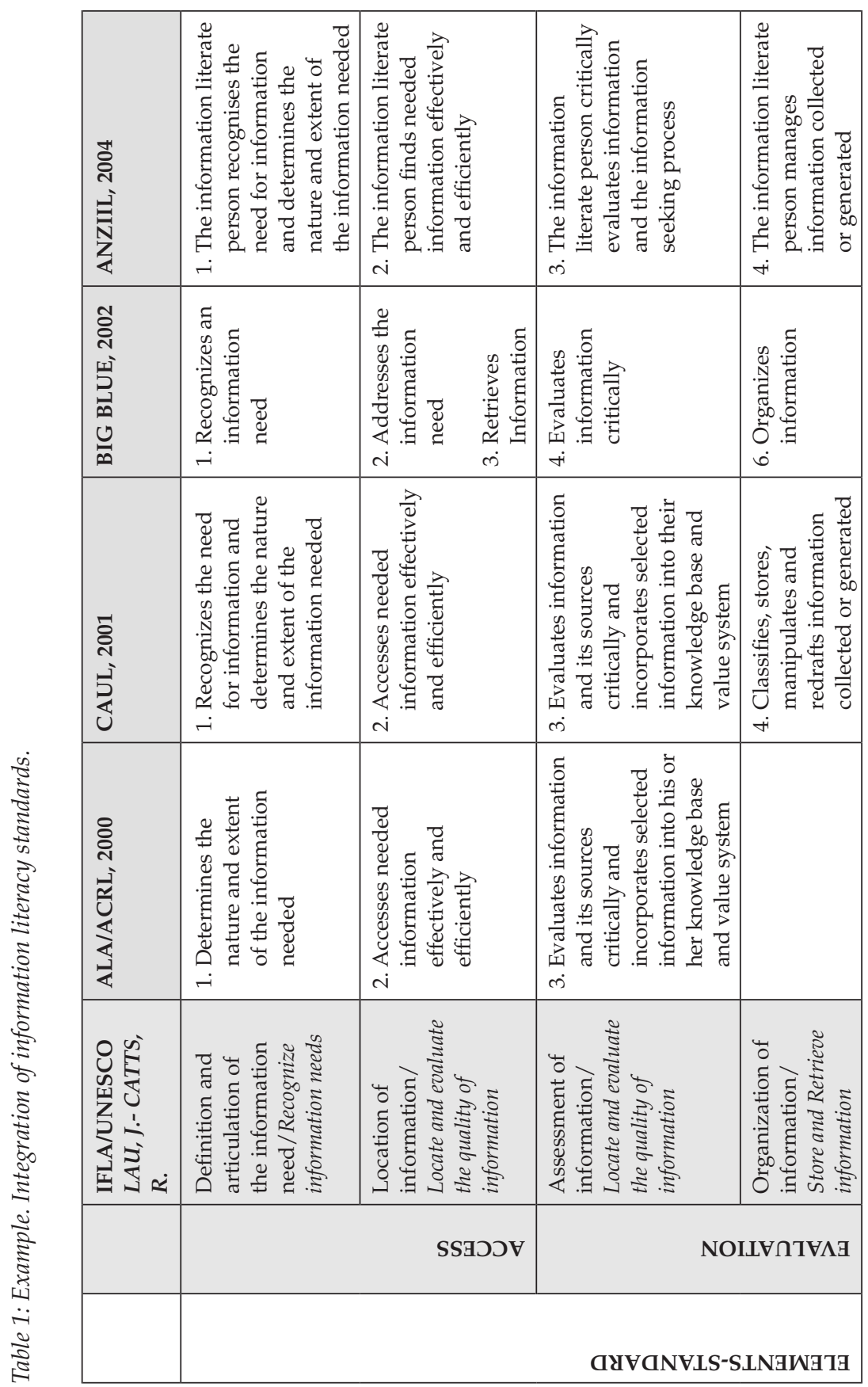




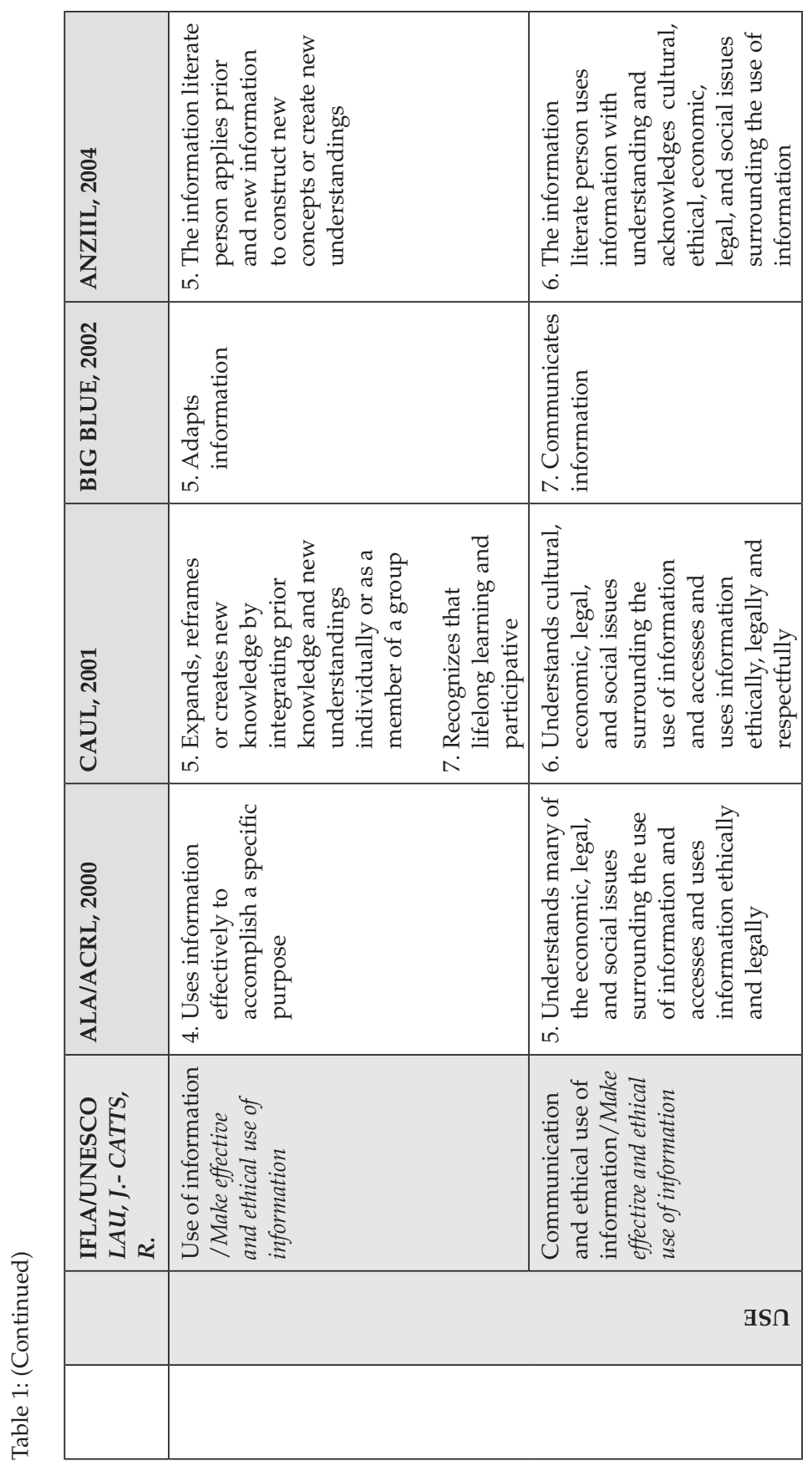


Based on IFLA's guidelines and UNESCO's indicators a content-analysis was then carried out, which allowed for the identification of differences and similarities, as shown in Figure 4, between the indicators and expected outcomes for every single macro and micro competency (Uribe-Tirado, 2010).

Based on the indicators and expected outcomes in the standard proposed by the ALA/ACRL, which form the basis of the majority of standards in different countries (CAUL, ANZIIL, Universidad Autónoma de Ciudad Juarez, etc.), an analysis of the indicators was carried out from the perspective of the four different components of the cycle of knowledge generation (conversion): tacit to tacit (Socialization), tacit to explicit (Exteriorization), explicit to explicit (Combination) and explicit to tacit (Internalization). A table was created for the analysis, allowing for the identification of indicators and expected outcomes and relating them to knowledge generation (conversion), as socialization, exteriorization, internalization and combination (Table 2):

Fig. 4: Graphic representation of the Integrated Information Literacy Model (Uribe-Tirado, 2010).

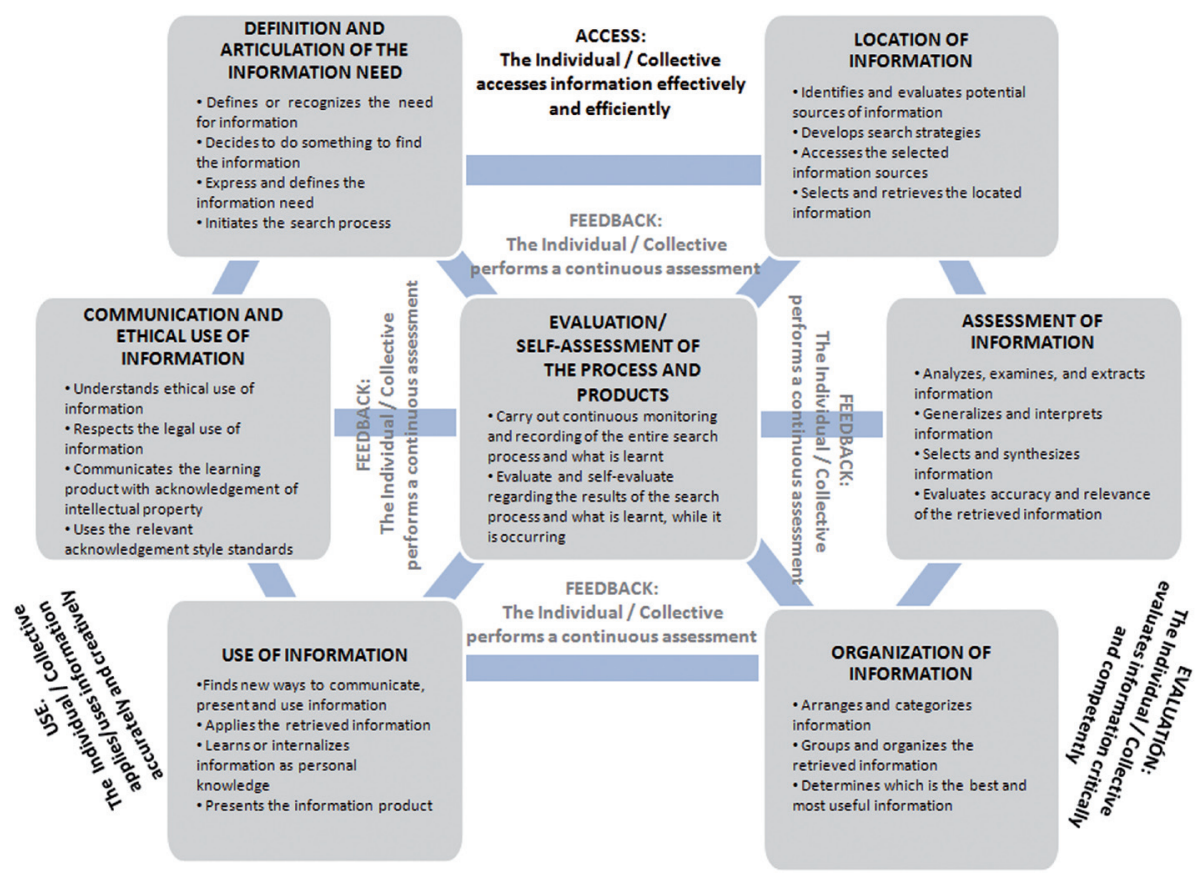




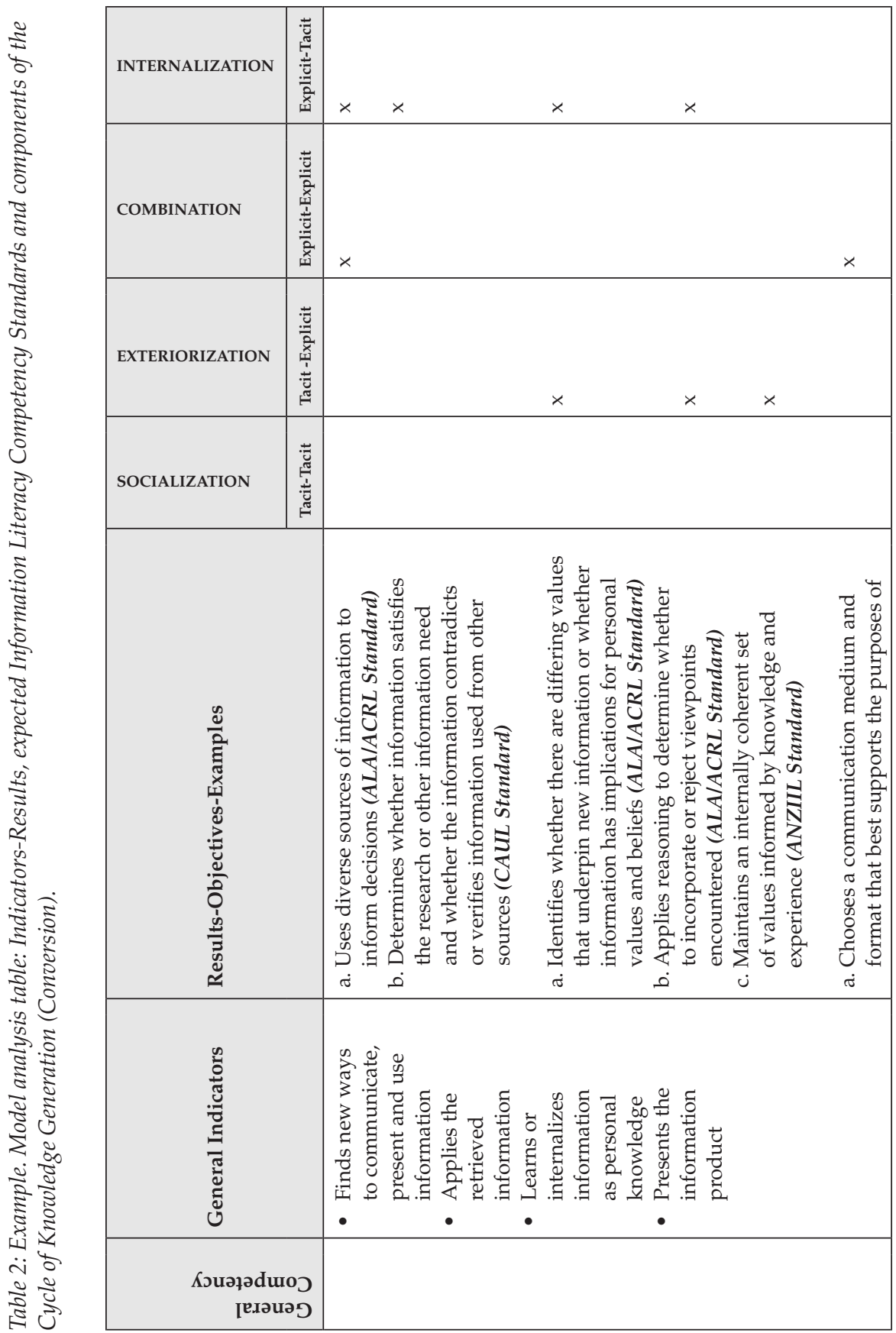


Alejandro Uribe Tirado and Wilson Castaño Muñoz

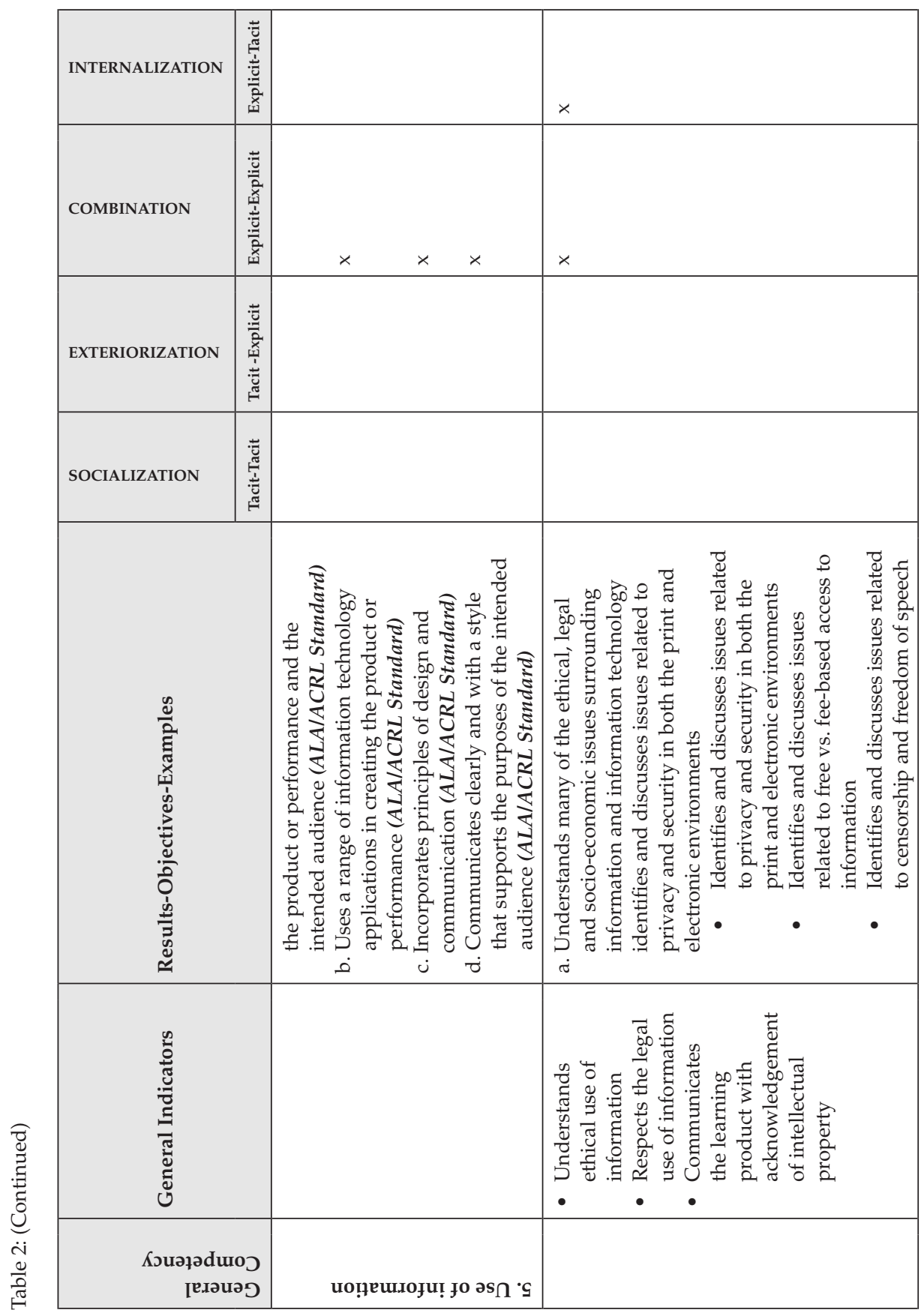




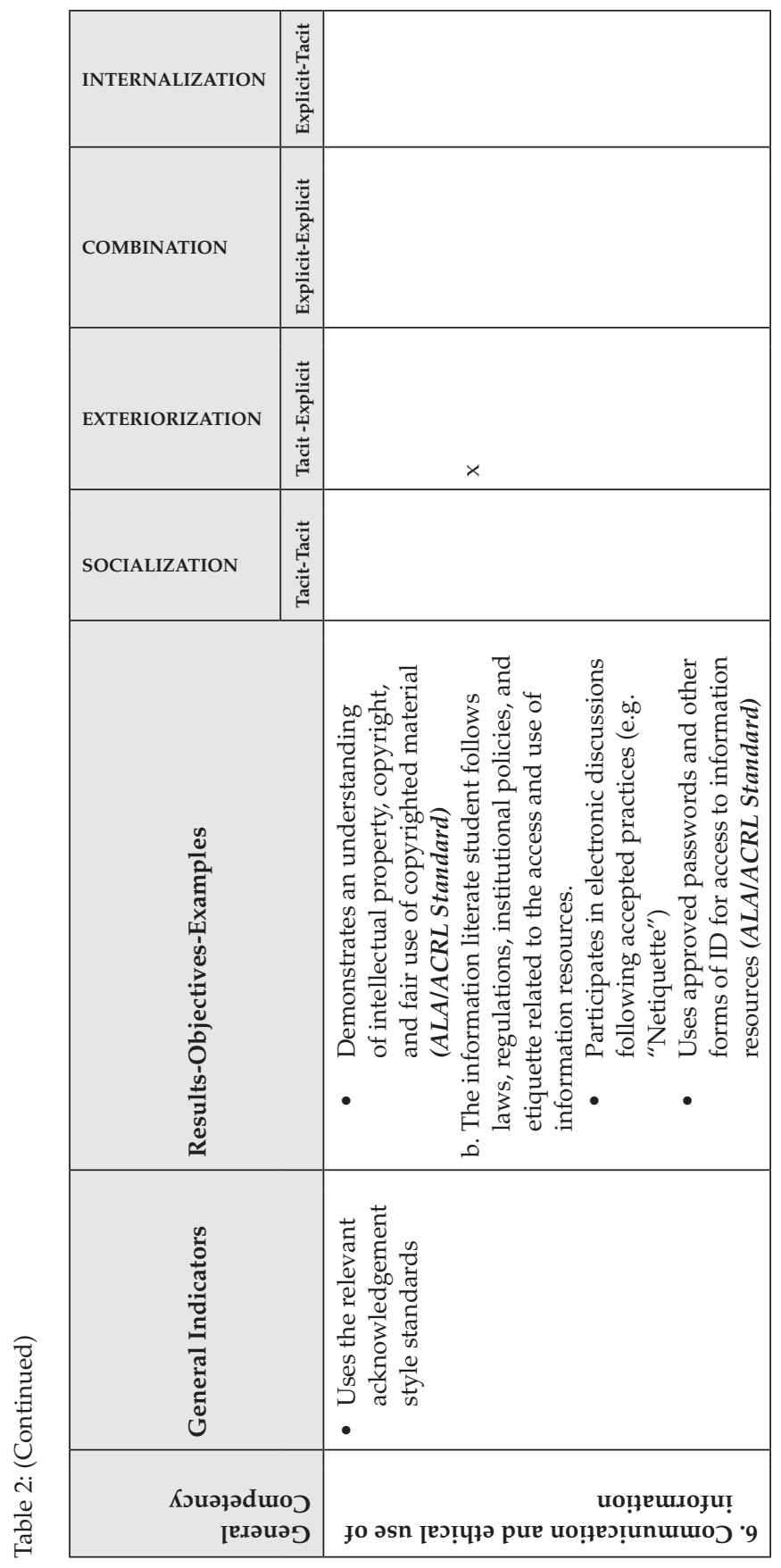




\section{Findings}

The analysis of this integrative table of Information Literacy Indicators that integrate the most important Higher Education Standards, generated the following results:

Table 3 shows that if we take each competency and the standards involved and analyze them in terms of information and tacit and explicit knowledge, there are certain standards that imply skills-job training along with a good knowledge of direct and indirect management processes of the combination type (location of information and assessment of information), and of the internalization type (assessment of information), as can be seen in the following indicators (outcomes):

- Identifies keywords, synonyms and related terms for the information needed

- Selects controlled vocabulary specific to the discipline or information retrieval source

- Uses various classification schemes and other systems (e.g., call number systems or indexes) to locate information resources within the library or to identify specific sites for physical exploration

- Restates textual concepts in his/her own words and selects data accurately

- Utilizes computer and other technologies (e.g., spreadsheets, databases, multimedia, and audio or visual equipment) for studying the interaction of ideas and other phenomena

(Integrated Information Literacy Standards: ALA/ACRL and other)

However, other competencies, standards and their relationships with these four knowledge management processes are needed, the results are low (Figure 5: Socialization and Exteriorization), indicating the need to review the emphasis on information and knowledge more explicit type that tacit, in training in information competencies (information literacy).

According to the findings of this research, we put forward that it is necessary to emphasize the following indicators (outcomes) for the behavior of an information literate person: 


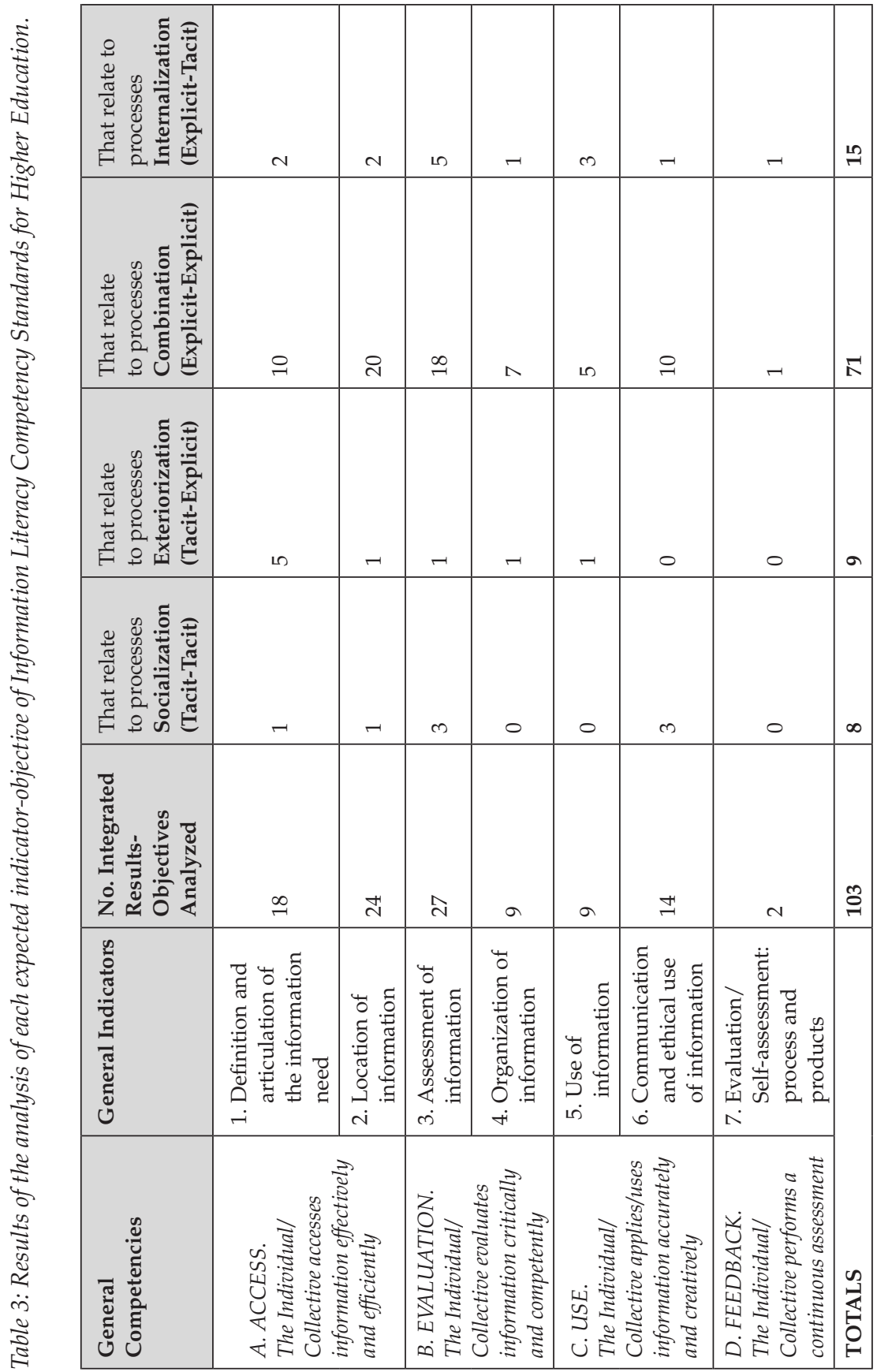


Fig. 5: Results when emphasizing certain forms of Knowledge generation (Conversion) of Information Literacy Competency Standards for Higher Education.

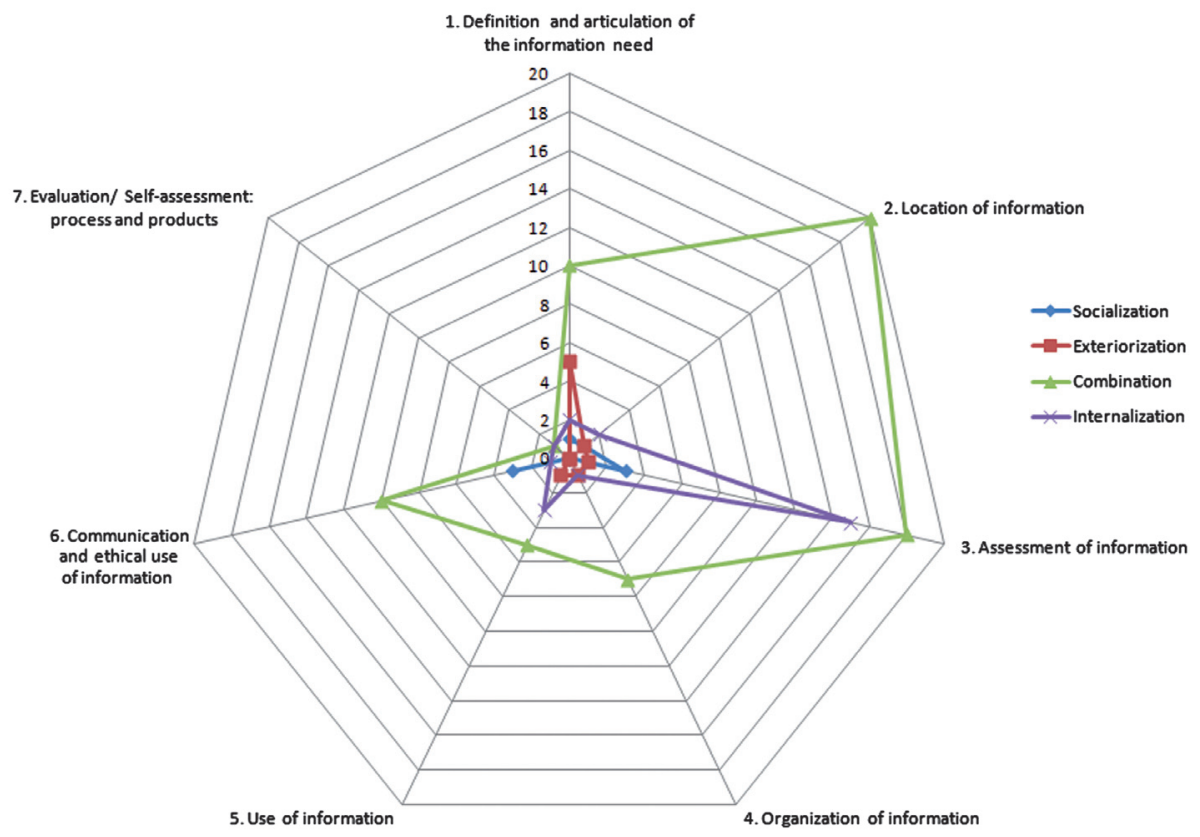

- Confers with instructors and participates in class discussions, peer workgroups, and electronic discussions to identify a research topic, or other information need

- Participates in class-sponsored electronic communication forums designed to encourage discourse on the topic (e.g., email, bulletin boards, chat rooms)

- Articulates knowledge and skills transferred from prior experiences to planning and creating the product or performance

- Identifies and discusses issues related to censorship and freedom of speech

(Integrated Information Literacy Standards: ALA/ACRL and other)

It is also necessary to propose and integrate new indicators for different information literacy competency standards for higher education (ACRL/ ALA, CAUL, ANZIIL, SCONUL, Ciudad Juárez), according to the different competencies and standards expected, for example: (We propose some as...) 
- Identify needs for personal-social or academic-labor information and the implications of differences between these for the searching for, locating, diffusing and ethical use of information.

- Know the difference between natural language and formal language as well as how to use them correctly in order to obtain good results in information searches, depending on the source, such as other people, twitter, blogs, databases or books etc.

- Evaluate the reliability of a comment in a classroom or in a social network.

- Use different strategies, media and tools for acquiring personal-social or academic-labor information depending on the length, complexity and copyright status of the information.

- Be aware of the implications for and impact on education, society, economics and/or politics of accurate or inaccurate information in social networks.

Information competencies are particularly necessary now that the paradigm of Web 2.0 has changed and is changing, as Web 2.0 involves new sources of information that are mainly created by users' experiences or tacit to explicit (Exteriorization), and in the light of new and sustained ways in which tacit to tacit (Socialization) information is disseminated by the multiple means of instantaneous and ubiquitous communication offered by current information technology.

\section{Conclusions}

Some general conclusions, as well as specific issues identified in the previous section, are:

The main goal of information literacy is knowledge generation, provided that appropriate information management is present; that is why it is necessary to recognize and correlate previous theoretical frameworks and tools which offer developments in knowledge management. This study therefore aims to be a source of reference for other studies, because Information Literacy is a prerequisite of Knowledge Management (Uribe-Tirado, 2005) and a key theme in the training of librarians XXI century (Castaño-Muñoz \& UribeTirado, 2011). At the same time, Knowledge Management contributes to the instructional process of IL. 
Even though Information Literacy standards in academic institutions are created based on the proposals put forward by ALA/ACRL (1999), there are additional elements and items in each of the proposals not only of form, but of substance, that it is important to be aware of in order to obtain a more complete framework of standards and indicators (objectives and expected outcomes), so that these can be adapted to countries (where national standards have not been established) or to academic institutions that want to implement them.

In academic institutions, current Information Literacy Standards, including their indicators and expected outcomes, place a major emphasis on the Knowledge Generation (conversion) processes of combination and internalization rather than the socialization and exteriorization processes, leading to a general emphasis on explicit knowledge. It is therefore necessary to consider implementing different indicators ${ }^{6}$, expected outcomes and goals, which will help to balance out this tendency in favor of tacit knowledge, because information behavior models for information searches and use indicated that other people and peers are key factors in influencing behavior and aid the clarification of information requirements (Uribe-Tirado, $2009 \mathrm{~b}$ ). Information behavior models can also assist with self-evaluation of processes and products, therefore re-initiating the cycle of information and knowledge management. It is necessary to consider, measure and evaluate information related to tacit knowledge both in the academic context as well as in other contexts (Lloyd, 2003; Ferguson \& Lloyd, 2007; Ferguson, 2009), thus permitting a broader view of information literacy.

\section{References}

ALA/ACRL (2000). Information Literacy Competency Standards for Higher Education. Retrieved September 29, 2012, from http:/ / www.ala.org/acrl/standards / informationliteracycompetency.

ALA/ACRL (2001). Objectives for Information Literacy Instruction: A Model Statement for Academic Librarians. Retrieved September 29, 2012, from http:/ /www.ala.org/acrl/ standards/objectivesinformation.

Alavi, M., and Leidner, D.E. (2001). Review: Knowledge management and knowledge management systems: Conceptual foundations and research issues. MIS 
Quarterly, 25, 107-136. Retrieved September 4, 2008, from http:/ /mgmt.iisc.ernet. in/ piyer/Knowledge_Management/KM\%20and \%20KMS\%20Conceptual\%20 Foundations \%20and\%20Research\%20Issues \%20MIS\%20Quarterly\%2025\%201\%20 March\%20201.pdf.

Andretta, S. (2005). Information literacy: A practitioner's guide. Oxford: Chandos.

ANZIIL (2004). Australian and New Zealand Information Literacy Framework. Retrieved October 10, 2009, from http:/ / www.caul.edu.au/content/upload/files/infoliteracy/InfoLiteracyFramework.pdf.

Basili, C. (2003). Information literacy in Europe: A first insight into the state of the art of information literacy in the European Union. Roma: Consiglio Nazionale delle Ricerche.

Becerra, M., Lunnan, R., and Huemer, L. (2008). Trustworthiness, risk, and the transfer of tacit and explicit knowledge between alliance partners. Journal of Management Studies, 45, 691-713.

Behrens, S.J. (1994). A conceptual analysis and historical overview of information literacy. College and Research Libraries 55, 309-322.

Bruce, C.S., and Candy, P. (2000). Information literacy around the world: Advances in programs and research. Wagga, N.S.W.: Centre for Information Studies, Charles Sturt University.

Castaño-Muñoz, W., and Uribe-Tirado, A. (2011). Identifying information behavior in information search and retrieval through learning activities using an E-learning platform case: Interamerican school of library and information science at the University of Antioquia. Education Libraries. Special Libraries Association, 34(1), 33-49. Retrieved September 4, 2012, from http:/ / eprints.rclis.org/handle/10760/15988.

Catts, R., and Lau, J. (2008). Towards information literacy indicators. Paris: UNESCO. Retrieved October 16, 2012, from http:/ / www.ifla.org/files/assets/informationliteracy/publications/towards-information-literacy_2008-en.pdf

CAUL (2001). Information literacy standards. Canberra: Council of Australian university librarians. Retrieved October 10, 2009, from http:/ /archive.caul.edu.au/ caul-doc/InfoLitStandards2001.doc.

CILIP (2004). CILIP's definition on information literacy. Chartered Institute of Library and Information Professionals. Retrieved September 29, 2012 from http:/ / www.cilip.org.uk/get-involved/advocacy/information-literacy/pages / definition.aspx.

Choo, C. (1999). La organización inteligente. Oxford: Oxford University Press.

Cortés, J., and Lau, J. (2004). Normas de alfabetización informativa para el aprendizaje. México: UACJ. 
Cuevas Cerveró, A. (2007). Lectura, alfabetización en información y biblioteca escolar. Gijón: Ediciones TREA, S.L.

Davenport, T.H. (2008, February 19). Enterprise 2.0: The new, new knowledge management? Harvard Business Online. Retrieved November 7, 2012, from http:/ / blogs.hbr.org/davenport/2008/02/enterprise_20_the_new_new_know_1.html.

Davenport, T.H., and Prusak, L. (1998). Working knowledge: How organizations manage what they know. Boston, MA: Harvard Business School Press.

Dudziak, E.A. (2003). Information literacy: Princípios, filosofia e prática. Ciência da Informação, 32, 23-35. Retrieved October 10, 2009, from http:/ / eprints.rclis. org/4727/1/ DUDZIAKCi.Inf-2004-156.pdf.

Easterby-Smith, M., and Lyles, M. (2003). The Blackwell handbook of organizational learning and knowledge management. Australia: Blackwell Publishing.

Ferguson, S. (2009). Information literacy and its relationship to knowledge management. Journal of Information Literacy, 3(2), 6-24. Retrieved June 21, 2010, from http:/ / ojs.lboro.ac.uk/ojs/index.php/JIL/ article/view/PRA-V3-I2-2009-1.

Ferguson, S., and Lloyd, A. (2007). Information literacy and the leveraging of corporate knowledge. In S. Ferguson (ed.), Libraries in the twenty-first century: Mapping future directions in information services (pp. 221-239). Wagga Wagga, NSW: Centre for Information Studies.

Garner, S.D. (2006). Alexandria proclamation on information literacy and lifelong learning. Retrieved October 1, 2007, from http:/ /archive.ifla.org/III/wsis/High-LevelColloquium.pdf.

Geisler, E., and Wickramasinghe, N. (2009). Principles of knowledge management: Theory, practice and cases. New York: M. E. Sharpe Incorporated.

Gibson, C. (2008). The history of information literacy. In E. Blakesley Lindsay and C.N. Cox (eds.), Information Literacy Handbook. Chicago: ALA, ACRL.

Grassian, E., and Kaplowitz, J.R. (2009). Information literacy instruction: Theory and practice (2nd ed.). New York: Neal-Schuman.

Horton, F.W. (Ed.) (2012). Worldwide multi-lingual information literacy resources. UNESCO (in editing process).

Ichijo, K., and Nonaka, I. (2006). Knowledge creation and management: New challenges for managers. New York: Oxford University Press.

JISC (2002). The main information literacy discussion list: Lis-infoliteracy. Retrieved October 10, 2009, from http:/ / www.jiscmail.ac.uk/lists/lis-infoliteracy.html.

Kuhlthau, C. (1985-2008). Information Search Process. Retrieved September 29, 2012, from http:/ / comminfo.rutgers.edu/ kuhlthau/information_search_process.htm. 
Lau, J. (2006). Guidelines on information literacy for lifelong learning. Boca del Río, Veracruz, México. Retrieved November 30, 2008, from http:/ / archive.ifla.org/VII/ s42/pub/IL-Guidelines2006.pdf.

Lau, J. (2007), Information Literacy: An international state-of-the-art report. UNESCOIFLA. Retrieved September 29, 2012 from http:/ /www.jesuslau.com/docs / publicaciones/doc2/UNESCO_state_of_the_art.pdf.

Lorenzen, M. (2001). A brief history of library information in the United States of America. Illinois Libraries, 83, 8-18.

Lloyd, A. (2003). Information literacy: The meta-competency of the knowledge economy? Journal of Librarianship and Information Science, 35(2), 87-92.

Markless, S., and Streatfield, D.R. (2007). Three decades of information literacy: redefining the parameters. In S. Andretta (ed.), Change and challenge: information literacy for the twenty-first century (pp. 15-36). Adelaide: Auslib Press.

Moore, P. (2005). An analysis of information literacy education worldwide. School Libraries Worldwide, 11(2), 1-23.

Nonaka, I., and Takeuchi, H. (1995). The knowledge-creating company: How Japanese companies create the dynamics of innovation. New York: Oxford University Press.

NORDINFO (2001). Information literacy. The Nordic Council for Scientific Information. Retrieved October 10, 2009, from http:/ / southernlibrarianship.icaap. org/content/v02n01/hannesdottir_s01.html.

Pinto, M. (2004). Alfabetización informativo digital. Granada: Universidad de Granada. Retrieved September 29, 2012, from http:/ / www.mariapinto.es/e-coms/alfa_infor. htm.

Pinto, M., Sales, D., and Osorio, P. (2007). Innovación educativa para el fomento de la alfabetización informacional en la educación superior: Los portales e-COMS, ALFINEEES, ALFAMEDIA e IMATEC. I Simposio Internacional de Documentación Educativa SIDOC 2007. Palma de Mallorca, de 14 al 16 de febrero. Retrieved May 12, 2009, from http:/ / www.doredin.mec.es/documentos/01220073000108.pdf.

Pinto, M., Uribe-Tirado, A., Gómez, R.D., and Cordon, J.A. (2011). La producción científica internacional sobre competencias informacionales e informáticas: tendencias e interrelaciones. Información, Cultura y Sociedad. Publicación del Instituto de Investigaciones Bibliotecológicas (FFyL-UBA), 24, 29-62. Retrieved September 29, 2012, from http:/ / ppct.caicyt.gov.ar/index.php/ics/article/view/646/824.

Rader, H.B. (2002). Information literacy 1973-2002: A selected literature review bibliography. Library Trends, 51, 242-259. 
Rader, H.B. (2003). Information literacy: A global perspective. In A. Martin and H.B. Rader (eds.), Information and IT literacy: Enabling learning in the 21st century (pp. 24-42). London: Facet Publishing.

Saranto, K., and Hovenga, E. (2004). Information literacy — What's about? Literature review of the concept and the context international. Journal of Medical Informatics, 73(6), 503-513.

SCONUL - Society of College, National and University Libraries (1999). Information skills in higher education: a SCONUL position paper. Retrieved March 22, 2009, from http://www.sconul.ac.uk/groups/information_literacy/papers/Seven_pillars.html.

Spanish Translation: ALFIN: La definición de CILIP (translated by Cristóbal Pasadas Ureña). Boletín de la Asociación Andaluza de Bibliotecarios, 77, 79-84. Retrieved October 10, 2009, from http:/ / www.aab.es/pdfs/baab77/77a4.pdf.

Spender, J.-C., and Scherer, A.G. (2007). The philosophical foundations of knowledge management. Editors' Introduction. Organization, 14, 5-28.

Tsoukas, H. (2005). Complex knowledge: Studies in organizational epistemology. Oxford: Oxford University Press.

UNESCO/NFIL (2003). The Prague declaration: towards an information literate society. Retrieved October 1, 2007, from http:/ / portal.unesco.org/ci/en/files/19636/1122886 3531PragueDeclaration.pdf/PragueDeclaration.pdf.

Uribe-Tirado, A. (2005). La alfabetización informacional, un prerrequisito y campo de acción para la e-inclusión y la gestión del conocimiento en red en las universidades. In: XII Congreso Internacional de Educación Electrónica, Virtual y a Distancia TELEDUMED. Retrieved December 15, 2009, from http:/ / eprints.rclis.org/15064/.

Uribe-Tirado, A. (2008). Diseño e implementación y evaluación de una propuesta formativa en alfabetización informacional mediante un ambiente virtual de aprendizaje a nivel universitario: caso Escuela Interamericana de Bibliotecología, Universidad de Antioquía. Maestría en Ingeniería, Línea Informática Educativa. Universidad EAFIT (Colombia). Retrieved July 18, 2009, from http:/ / eprints.rclis.org/handle/10760/12606.

Uribe-Tirado, A. (2009a). Interrelaciones entre veinte definiciones-descripciones del concepto de alfabetización informacional: propuesta de macro-definición. ACIMED. Revista cubana de los profesionales de la información y de la comunicación en salud, 20, n.

Uribe-Tirado, A. (2009b). El conocimiento y reconocimiento de los modelos de comportamiento informacional. Un aspecto necesario para los servicios de información Web 2.0 y la alfabetización informacional-DHI desde las bibliotecas. In: Memorias XVI Coloquio Internacional de Bibliotecarios. Guadalajara, México: Feria Internacional del Libro FIL.

Uribe-Tirado, A. (2010). Lecciones aprendidas en programas de alfabetización informacional en universidades de Iberoamérica (Avance Tesis Doctoral). Universidad de GranadaEspaña. 
Van Dijk, J. (2005). The deepening divide: Inequality in the information society. London: Sage.

Vera, D., and Crossan, M. (2003). Organizational learning and knowledge management: Toward an integrative framework. In M. Easterby-Smith and M.A. Lyles (eds.), The Blackwell handbook of organizational learning and knowledge management. Australia: Blackwell Publishing.

Virkus, S. (2003). Information literacy in Europe: a literature review. Information Research, 8,4. Retrieved May 5, 2008, from http://informationr.net/ir/8-4/paper159. html.

Webber, S., and Johnston, B. (2000). Conceptions of information literacy: new perspectives and implications. Journal of Information Science, 26, 381-397. doi: $10.1177 / 016555150002600602$.

Webber, S., and Johnston, B. (2006). Information literacy: definitions and models. Retrieved May 5, 2008, from http:/ /dis.shef.ac.uk/literacy/definitions.htm.

Zurkowski, P. G. (1974). The information service environment: Relationships and priorities. Washington, DC: National Commission on Libraries and Information Science.

\section{Notes}

${ }^{1}$ This article is the result of $\mathrm{PhD}$ research on Information Literacy: "Lesson learned in information literacy programs in Ibero-American universities" University of Granada (Spain).

${ }^{2}$ Davenport \& Prusak (1998); Choo (1999); Nonaka \& Takeuchi (1995); Alavi \& Leidner (2001); Tsoukas (2005); Ichijo \& Nonaka (2006); Spender \& Scherer (2007); Becerra, Lunnan \& Huemer (2008); Davenport (2008); Geisler \& Wickramasinghe (2009) etc.

${ }^{3}$ http:/ / www.gdrc.org/kmgmt/what-is-km.html — http:/ /blog.simslearningcon nections.com $/ \mathrm{p}=279$

${ }^{4}$ Behrens (1994); Bruce \& Candy (2000); Lorenzen (2001); Rader (2002, 2003); Webber \& Johnston (2000, 2006); Basili (2003); Dudziak (2003); Virkus (2003); Andretta (2005); Moore (2005); Gibson (2008); Grassian \& Kaplowitz (2009); Pinto, Uribe-Tirado, Gómez-Díaz \& Cordón (2011).

${ }^{5}$ This analysis considered the standard of 1999, but recently it has been modified by SCONUL (April 2011): “In 1999, The SCONUL Working Group on Information Literacy published Information Skills in Higher Education: a SCONUL Position Paper (SCONUL, 1999), introducing the Seven Pillars of Information Skills model. 
Since then, the model has been adopted by librarians and teachers around the world as a means of helping them to deliver information skills to their learners. However, in 2011 we live in a very different information world and while the basic principles underpinning the original Seven Pillars model remain valid, it was felt that the model needed to be updated and expanded to reflect more clearly the range of different terminologies and concepts which we now understand as "Information Literacy". In order for the model to be relevant to different user communities and ages, the new model is presented as a generic "core" model for Higher Education, to which a series of "lenses", representing the different groups of learners, can be applied". See: http://www.sconul.ac.uk/groups/information_literacy/seven_pillars.html.

${ }^{6}$ Unfortunately, the recent changed "Seven Pillars of Information Literacy 2011 model", still shows an almost entirely majority emphasis for the explicit information and knowledge ("skills and attributes"), which is tacit. See: http:/ /www.sconul. ac.uk/groups/information_literacy/diagrams.html. 